\title{
Correction to: Nicotinamide riboside as a neuroprotective therapy for glaucoma: study protocol for a randomized, double- blind, placebo-control trial
}

Christopher Kai Shun Leung ${ }^{1,2,3^{*}}$, Seraph Tianmin Ren ${ }^{3}$, Poemen Pui Man Chan ${ }^{2,3}$, Kelvin Ho Nam Wan ${ }^{2,3}$, Aziz Ka Wai Kam ${ }^{3}$, Gilda Wing Ki Lai ${ }^{1}$, Vivian Sheung Man Chiu', Match Wai Lun Ko ${ }^{4}$, Cedric Ka Fai Yiu ${ }^{5}$ and Marco Chak Yan Yu

\section{Correction to: Leung 23:45 (2022)}

\section{https://doi.org/10.1186/s13063-021-05968-1}

Following the publication of the original article [1], we were notified that the received date of the paper was 26 November 2020, and not 8 March 2021.

The original article has been corrected.

\section{Author details}

1Department of Ophthalmology, LKS Faculty of Medicine, The University of Hong Kong, Hong Kong, People's Republic of China. ${ }^{2}$ Hong Kong Eye Hospital, Hong Kong, People's Republic of China. ${ }^{3}$ Department of Ophthalmology and Visual Sciences, The Chinese University of Hong Kong, Hong Kong, People's Republic of China. ${ }^{4}$ Department of Mechanical Engineering, University of Hong Kong, Hong Kong, People's Republic of China. ${ }^{5}$ Department of Applied Mathematics, Hong Kong Polytechnic University, Hong Kong, People's Republic of China. ${ }^{6}$ Singapore Eye Research Institute, Singapore, Singapore.

Published online: 10 February 2022

\section{Reference}

1. Leung, et al. Nicotinamide riboside as a neuroprotective therapy for glaucoma: study protocol for a randomized, double-blind, placebo-control. Trial. 2022;23:45. https://doi.org/10.1186/s13063-021-05968-1.

\footnotetext{
The original article can be found online at https://doi.org/10.1186/s13063021-05968-1.

* Correspondence: cleung21@hku.hk

'Department of Ophthalmology, LKS Faculty of Medicine, The University of Hong Kong, Hong Kong, People's Republic of China

${ }^{2}$ Hong Kong Eye Hospital, Hong Kong, People's Republic of China

Full list of author information is available at the end of the article
}

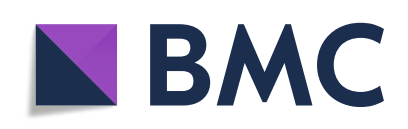

(- The Author(s). 2022 Open Access This article is licensed under a Creative Commons Attribution 4.0 International License, which permits use, sharing, adaptation, distribution and reproduction in any medium or format, as long as you give appropriate credit to the original author(s) and the source, provide a link to the Creative Commons licence, and indicate if changes were made. The images or other third party material in this article are included in the article's Creative Commons licence, unless indicated otherwise in a credit line to the material. If material is not included in the article's Creative Commons licence and your intended use is not permitted by statutory regulation or exceeds the permitted use, you will need to obtain permission directly from the copyright holder. To view a copy of this licence, visit http://creativecommons.org/licenses/by/4.0/. The Creative Commons Public Domain Dedication waiver (http://creativecommons.org/publicdomain/zero/1.0/) applies to the data made available in this article, unless otherwise stated in a credit line to the data. 